\section{Preharvest Calcium Sprays Do Not Improve Highbush Blueberry (Vaccinium corymbosum L.) Quality}

\author{
Eric J. Hanson \\ Department of Horticulture, Michigan State University, East Lansing, \\ MI 48824
}

Additional index words. firmness, Nutrical

\begin{abstract}
Calcium sprays were applied to 'Bluecrop' highbush blueberry bushes between petal fall and fruit harvest. In 1992, bushes received five sprays between 18 June and 16 July that totaled $0,1.0,1.9$ or $3.8 \mathrm{~kg} \mathrm{Ca} / \mathrm{ha}$. Calcium was applied as $\mathrm{CaCl}_{2}$ at spray concentrations of $0.08 \%$ to $0.2 \%$ Ca. Treatments in 1993 consisted of a control; 12.1 and $24.2 \mathrm{~kg} \mathrm{Ca} / \mathrm{ha}$ as $\mathrm{CaCl}_{2}$; and $12.1 \mathrm{~kg} \mathrm{Ca} / \mathrm{ha}$ as the commercial product Nutrical. Calcium was applied in seven sprays between $4 \mathrm{June}$ and $16 \mathrm{July}$ using spray concentrations of $0.1 \%$ to $0.4 \%$ Ca. Berry samples were hand-picked, stored for 3 to 20 days, and evaluated. Treatments had no effect on the percentage of soft or rotten berries, berry firmness, or berry Ca concentrations during either year. Calcium applications increased leaf Ca concentrations. Chemical names used: calcium trihydroxyglutarate (Nutrical).
\end{abstract}

Firmness is an important quality characteristic of fresh blueberries. Berries are often too soft if harvested when over-mature, physically damaged (bruised) during harvesting and handling, or infected by fungi that cause postharvest decay. Berries softened by bruising also are predisposed to postharvest decay (Ballinger et al., 1973). Techniques to increase or maintain blueberry firmness would be highly desirable.

\section{Materials and Methods}

Preharvest Ca sprays increased the firmness of strawberries (Fragaria Xananassa Duch.) (Eaves and Leefe, 1962) and raspberries (Eaves et al., 1972). Dipping picked berries in $\mathrm{CaCl}_{2}$ solutions increased the firmness of highbush blueberries (Hanson et al., 1993), but dips left an objectionable salty taste. My studies tested whether preharvest $\mathrm{Ca}$ sprays would enhance berry quality. Studies were conducted for 2 years in a 1979 planting of 'Bluecrop' bushes in Bloomingdale, Mich. The soil had a loamy sand texture; $\mathrm{pH}$ of 4.4 ; and $\mathrm{P}, \mathrm{K}, \mathrm{Ca}$, and $\mathrm{Mg}$ levels of 207, 110, 170, and $82 \mathrm{~kg} \cdot \mathrm{ha}^{-1}$, respectively.

In 1992, treatments supplied a total of either $0,1.0,1.9$, or $3.8 \mathrm{~kg} \mathrm{Ca} / \mathrm{ha}$. Calcium was applied as $\mathrm{CaCl}_{2}$ in a series of five sprays between 18 June (berry diameter 3 to $6 \mathrm{~mm}$ ) and 16 July (first ripe berries). Spray concentrations were lowest on the first application

Received for publication 31 Oct. 1994. Accepted for publication 30 Mar. 1995. We acknowledge the Michigan Agricultural Expt. Station and MBGMarketing, Grand Junction, Mich., for support of this work. The cost of publishing this paper was defrayed in part by the payment of page charges. Under postal regulations, this paper therefore must be hereby marked advertisement solely to indicate this fact.

HortScience, Vol. 30(5), August 1995
The phytotoxicity of $\mathrm{CaCl}_{2}$ and the chelated Ca product Nutrical (CSIChemical Corp., Bondurant, Iowa) were tested in a separate study. Four 20- to 40-cm-long branches of 'Jersey' bushes were sprayed on 29 June 1992 to the point of drip (abaxial and adaxial leaf surfaces were wet) with water or $0.17 \%, 0.34 \%$, $0.51 \%$, or $0.68 \% \mathrm{Ca}$, as either $\mathrm{CaCl}_{2}$ or Nutrical. Leaves were removed after 10 days, and the healthy and necrotic tissues were separated and weighed.

In 1993, higher rates of $\mathrm{Ca}$ and a second $\mathrm{Ca}$ source were tested. Treatments consisted of a nontreated control, $12.1 \mathrm{~kg} \mathrm{Ca} / \mathrm{ha}$ as $\mathrm{CaCl}_{2}$, $24.2 \mathrm{~kg} \mathrm{Ca} / \mathrm{ha}$ as $\mathrm{CaCl}_{2}$, and $12.1 \mathrm{~kg} \mathrm{Ca} / \mathrm{ha}$ as Nutrical. These season totals were applied in seven sprays at 5- to 7-day intervals between 4 June (petal fall to 3- to 6-mm berries) and 16 July. Spray volume and $\mathrm{Ca}$ concentrations were lowest on the first application date (560 liters.ha ${ }^{-1}, 0.05 \%$ and $0.1 \% \mathrm{Ca}$ for the treatments receiving 12.1 and $24.2 \mathrm{~kg} \mathrm{Ca} / \mathrm{ha}$ ) and were increased progressively to maximum levels on the last spray date ( 930 liters.ha ${ }^{-1}, 0.2 \%$ and $0.4 \% \mathrm{Ca}$ ). The design was a randomized complete block with six replications and four bushes per plot.

Four 0.5-liter berry samples were harvested from each plot on 21 July and 1 Aug. Berries were placed in 0.5-liter plastic "clam shell" containers, arranged in flats, wrapped loosely in plastic bags, and placed at 2C. Half of berries from the first picking were removed from the cooler after 10 days and held at $18 \mathrm{C}$ for 1 day before evaluation. The second half were removed from the cooler after 17 days, and held at $18 \mathrm{C}$ for 1 day before evaluation. Berries from the second picking were evaluated after 10 days at $2 \mathrm{C}$ plus 1 day at $18 \mathrm{C}$ or after 19 days at $2 \mathrm{C}$ plus 1 day at $18 \mathrm{C}$. The percentage of soft and rotten berries was recorded as in 1992.

In 1993, berry firmness was measured with a instrument that squeezed individual berries between two parallel surfaces and recorded force $(g)$ vs. deformation (millimeters) (Timm et al., 1993). Six berries of similar size were selected from samples harvested from each plot on 24 July (first picking), and 12 berries per plot were selected on 1 Aug (second picking). Berries were arranged on trays in 3.8liter plastic bags, and placed in a $2 \mathrm{C}$ cooler. Each berry from the first picking was assessed at $4,7,12,21$, and 28 days after harvest and those from the second picking 17 and 24 days after harvest. Berries were allowed to warm to $18 \mathrm{C}$ before measurements were made, then returned to the cooler until the next evaluation date.

Leaf and fruit Ca concentrations were measured in 1992 and 1993. Thirty leaves were collected from each plot on 24 July 1992 and 21 July 1993 . Leaves were rinsed briefly in tap water (electrical conductivity $0.7 \mathrm{dS} \cdot \mathrm{m}^{-1}, 80$ to $100 \mathrm{mg} \mathrm{Ca} /$ liter), dried at 60C for 5 to 10 days, and ground to pass through a $0.6-\mathrm{mm}$ screen. Tissue was ashed at 550C and analyzed for $\mathrm{Ca}$ with a DC plasma emission spectrophotometer (Beckman Instruments, Fullerton, Calif.). Fruit samples, consisting of 30 to 40 mature berries, were freeze-dried, ground to pass through a $0.6-\mathrm{mm}$ screen, ashed at $550 \mathrm{C}$, and analyzed for Ca by atomic absorption spectrophotometry. 
Analysis of variance was conducted on all data. When $\mathrm{F}$ test indicated a significant treatment effect $(P=0.05)$, Tukey's least significant difference was used to separate means.

\section{Results and Discussion}

Sprays in 1992 that supplied $0,0.9,1.9$, or $3.8 \mathrm{~kg} \mathrm{Ca} / \mathrm{ha}$ had no effect on the percentage of soft $(5.9 \%$ to $10.2 \%)$ or moldy $(20.7 \%$ to $28.6 \%$ ) berries or compression of a column of berries (114 to $127 \mathrm{~cm}^{3}$ ) measured by compression after 12 days of storage. Treatments also had no effect on these measurements after 3 days of storage, when overall means were $6.6 \%$ soft, $4.9 \%$ moldy, and $98 \mathrm{~cm}^{3}$ for the compression tests. Treatments did not affect $\mathrm{Ca}$ concentrations in mature berries (310 to $346 \mu \mathrm{g} \cdot \mathrm{g}^{-1}$ dry weight $)$ or leaves $(0.25 \%$ to $0.29 \%$ dry weight).

Sprays in 1993 that supplied $\leq 24.2 \mathrm{~kg} \mathrm{Ca} / \mathrm{ha}$ also had no effect on the percentage of moldy berries or berries rated soft by touch after 11 days storage (overall means: $1.4 \%$ moldy, $4.0 \%$ soft) or 18 days storage $(0.7 \%$ moldy, $5.6 \%$ soft). Treatments also had no effect on fruit from the second commercial picking that were stored for 11 days ( $4.3 \%$ moldy, $10.3 \%$ soft) or 20 days ( $10.1 \%$ moldy, $22.5 \%$ soft). The firmness of berries from the first and second pickings also were monitored with a firmness meter for $\leq 28$ days after harvest. Treatments had no effect on firmness measurements on any date. Firmness averaged 81 or $56 \mathrm{~g} / \mathrm{mm}$ deformation for berries from the first and second picking, respectively. Leaf $\mathrm{Ca}$ concentrations were significantly higher $(P \leq$ 0.05 ) in bushes receiving $24.2 \mathrm{~kg} \mathrm{Ca} / \mathrm{ha}$ as $\mathrm{CaCl}_{2}(0.44 \% \mathrm{Ca}$ dry-weight basis) and 12.1 $\mathrm{kg} \mathrm{Ca} / \mathrm{ha}$ as Nutrical $(0.45 \% \mathrm{Ca})$ than in control plants $(0.41 \%)$. Fruit Ca concentrations were not affected by treatments (overall mean: $424 \mu \mathrm{g} \mathrm{Ca} / \mathrm{g}$ ).

Although postharvest $\mathrm{Ca}$ dips have improved blueberry firmness (Hanson et al., 1993), these preharvest sprays had no effect on berry $\mathrm{Ca}$ levels or firmness. Postharvest dips may have been effective because the whole fruit surface is treated and higher Ca concentrations were used in the dip solutions $(\leq 4 \%)$ than in spray solutions $(\leq 0.4 \%)$.

Using higher spray concentrations likely would cause unacceptable necrosis to leaf tissue. Sprays containing $0 \%$ to $0.7 \% \mathrm{Ca}$ applied to 'Jersey' bushes to the point of drip resulted in a linear increase in leaf injury [percent injury $=7.38($ percent $\mathrm{Ca})-0.22, R^{2}$ $=0.68]$. Calcium chloride and Nutrical resulted in similar levels of injury. Generally, $0.17 \%$ Ca sprays caused necrosis of $\approx 1 \%$ of the leaf weight, whereas $0.7 \% \mathrm{Ca}$ solutions caused necrosis of $3 \%$ to $7 \%$ of the leaf tissue.
Whether Ca sprays would improve the quality of varieties with softer berries than 'Bluecrop' or where berries are inadvertently harvested when over-mature or bruised during harvesting or handling is not known. Tests also may be warranted on plants containing inadequate $\mathrm{Ca}$ levels because leaf $\mathrm{Ca}$ levels in these studies $(0.25 \%$ to $0.45 \%)$ appeared adequate.

\section{Literature Cited}

Ballinger, W.E., L.J. Kushman, and D.D. Hamann. 1973. Factors affecting the firmness of highbush blueberries. J. Amer. Soc. Hort. Sci. 98:583587.

Eaves, C.A. and J.S. Leefe. 1962. Note on the influence of foliar sprays of calcium on the firmness of strawberries. Can. J. Plant Sci. 42:746-747.

Eaves, C.A., C.L. Lockhart, R. Stark, and D.L. Craig. 1972. Influence of preharvest sprays of calcium salts and wax on fruit quality of red raspberry. J. Amer. Soc. Hort. Sci. 97:706707.

Hanson, E.J., J.L. Beggs, and R.M. Beaudry. 1993. Applying calcium chloride postharvest to improve highbush blueberry firmness. HortScience 28:1033-1034.

Timm, E.J., P.R. Armstrong, G.K. Brown, and R.M. Beaudry. 1993. A portable instrument for measuring the firmness of cherries and berries. Amer. Soc. Agr. Eng. Trans. (In press.) 